\title{
Karawari carved crocodiles: From spirit-beings to museum artefacts
}

Les crocodiles sculptés du Karawari : d'êtres-esprits à objets de musée

\section{Borut Telban}

\section{(2) OpenEdition \\ 1 Journals}

\section{Electronic version}

URL: http://journals.openedition.org/jso/8838

DOI: $10.4000 /$ jso.8838

ISSN: $1760-7256$

Publisher

Société des océanistes

\section{Printed version}

Date of publication: 15 July 2018

Number of pages: $45-54$

ISBN: 978-2-85430-135-9

ISSN: 0300-953x

\section{Electronic reference}

Borut Telban, "Karawari carved crocodiles: From spirit-beings to museum artefacts », Journal de la Société des Océanistes [Online], 146 | 2018, Online since 15 July 2020, connection on 23 July 2020. URL : http://journals.openedition.org/jso/8838 ; DOI : https://doi.org/10.4000/jso.8838 


\title{
Karawari carved crocodiles: from spirit-beings to museum artefacts
}

by

\author{
Borut TELBAN*
}

\begin{abstract}
The Karawari River region of East Sepik Province, Papua New Guinea, is renowned for its lengthy, carved wooden crocodiles. These spirit-beings were kept in men's houses and had an important role in headhunting and war expeditions, initiation rituals, hunting trips, and during periods of epidemics. Karawari people acted upon the world with and through them. They were also sought by art collectors and found their way into museums around the world. Following the arrival of the Catholic charismatic movement in December 1994 the last men's houses in Ambonwari village were slowly abandoned as were the carved spirits hidden in them. The existence of these spirit-beings, however, has never been repudiated. In this article I examine an incident in which an outboard motor sank into a creek, and I seek an answer to the following question, posed in terms of Ambonwari cosmological mode of existence: How are the visible and invisible realms of carved spirit-crocodiles intertwined such that they can exist beyond their physical appearance?
\end{abstract}

KeYwords: carved crocodiles, spirits, dreams, Sepik art, Papua New Guinea

In the middle of September 2015, I visited the exhibition Myth + Magic: Art of the Sepik held at the National Gallery of Australia (NGA) in Canberra. The main organizer of the exhibition, which was on display between 7 August and 1 November 2015, was Crispin Howarth, the NGA curator of Pacific Art. The exhibition was timely:

\section{RÉSUMÉ}

La région de la rivière Korewori, dans la province de l'East Sepik, est connue pour ses longues sculptures de crocodiles en bois. Ces entités-esprits étaient conservés dans les maisons des hommes et jouaient un rôle important dans la chasse aux têtes, les expéditions guerrières, les rituels d'initiation, les expéditions de chasse et lors des épidémies. Les gens du Karawari agissaient sur le monde avec et à travers eux. Ces sculptures furent aussi recherchées par les collecteurs et finirent par rejoindre différents musées du monde. À la suite de l'implantation d'un courant catholique charismatique en décembre 1994, la dernière maison des hommes du village d'Ambonwari fut lentement abandonnée comme le furent ces sculptures des esprits qui y étaient cachées. Pourtant, l'existence de ces esprits n'a jamais été reniée. Dans cet article, janalyse un incident au cours duquel un moteur hors-bord sombra dans un chenal, et je cherche une réponse à la question suivante, posée sous l'angle du mode d'existence cosmologique d'Ambonwari : comment le monde visible et invisible des sculptures des esprits crocodiles s'entremêlent-ils au point quils puissent exister au-delà de leur présence physique?

Mots-CLÉs : sculpture crocodile, esprits, rêves, art du Sepik, Papouasie Nouvelle-Guinée

the fortieth anniversary of Papua New Guinea's independence was celebrated on 16 September 2015. One of the exhibition's highlights was an imposing 6.3 metres long wooden spirit-crocodile from the Karawari-speaking village of Kundiman (see photo 1), on loan from the Papua New Guinea National Museum and Art Gallery. Fewer

\footnotetext{
* Head of Anthropology Department, Institute of Anthropological and Spatial Studies, Research Centre of the Slovenian Academy of Sciences and Arts (ZRC SAZU); Coordinator of Anthropology program at the Postgraduate school ZRC SAZU, Borut.Telban@zrc-sazu.si.
} 


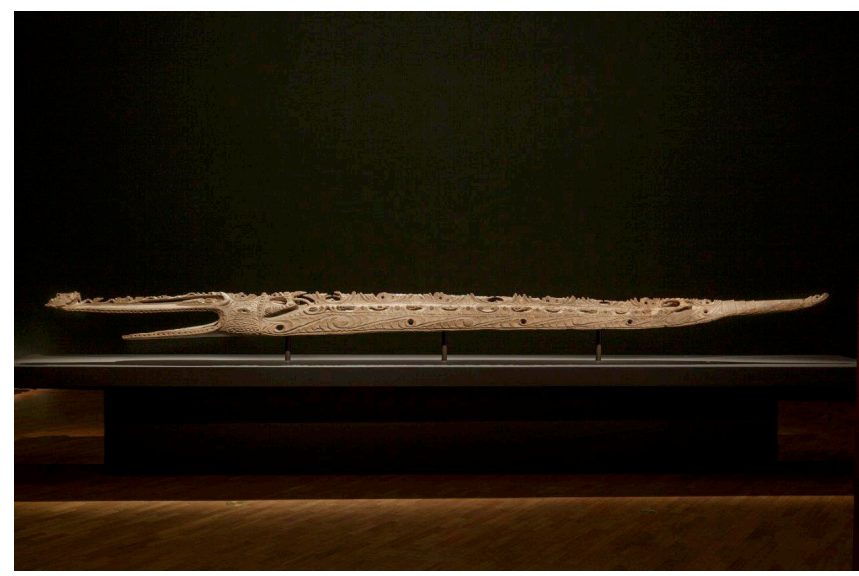

Рното 1. - Carved spirit-crocodile from the Karawari-speaking village of Kundiman (19 $9^{\text {th }}$ century), 2015 (Courtesy of the National Gallery of Australia)

than a dozen wooden crocodiles of this type are stored in the museums around the world, and this particular one is one of the few in that it had not been cut in pieces for the purpose of transportation (Howarth, pers. comm.; Kaufmann, pers. comm.).

Earlier that year a large number of objects from the Sepik River basin of Papua New Guinea were in succession exhibited first at the Berlin's Martin-Gropius-Bau, then at the Museum Rietberg in Zürich and finally, in October 2015, at the musée du quai Branly in Paris (see Peltier, Schindlbeck and Kaufmann, 2015a and 2015b). ${ }^{1}$ The majority of these objects were purchased and brought to Europe before the First World War. Again, two wooden spirit-crocodiles from the Karawari River area of Papua New Guinea occupied a prominent location in the exhibition (see photo 2).

Alfred Bühler (1961: 200) noted that the uses of wooden crocodiles in initiation and the preparation of hunting and war expeditions were unknown outside the Karawari area. Carved crocodiles were consulted by men at the beginning of head hunting raids. The men lifted the wooden spirit-crocodiles, which then showed them the direction of the planned head hunt. After a successful war expedition, the victims' heads were stuck into the mouths of the wooden crocodiles (Bühler, 1961: 200; see also Haberland, 1975; Tischner, 1965). Before the First World War and between 1930s and 1960s many objects, including the carved crocodiles, were purchased by collectors throughout the Karawari River area and later became important artefacts in museums in Port Moresby, Basel, Frankfurt, Hamburg, Geneva and New York (Bühler, 1961: 186; Craig, 1992: 94-95). A proclamation on 19 June 1936 prohibited the acquisition of two wooden crocodiles, carved with bone and stone tools, from Manjamai on the Karawari River (Craig, 1992: 75).

"This was the first proclamation and gazettal of specific objects, rather than classes of objects, in either Papua or New Guinea." (Craig, 1992: 75)

As I have been involved in anthropological and linguistic research among the Karawari-speaking people of Ambonwari since 1990, I immediately noticed, when looking at these wooden crocodiles at the two exhibitions, that the labels which accompanied them did not name them. I was not so much interested in what they were or what they represented but rather in who they were. They were introduced to spectators by the generic Karawari terms saki (bush spirit) or manbo (crocodile) and the village from which they were acquired. Just as it is the case with the majority of objects collected and shown in museums, there was no personal name of a spirit-being, no indication of ownership by a specific clan, its men's house, its myth of origin and the land to which they originally belonged. My first thought was that the absence of this information, extremely important for individual clans in the local context, depersonalized the carved crocodiles and transformed them from spirit-beings to spiritless artefacts. A second thought, however, was that just as these spirit-beings continue to exist among the Karawari-speaking people even when they are not given carved form, so do carved crocodiles continue to exist as spirit-beings even when their invisible realm is not explicitly presented and articulated to the viewer. One could say that in both cases they are simply not in their active mode of existence. They are dormant.

In what follows I will recapitulate an event when the carved spirit-crocodiles were approached in order to recover an outboard motor that had sunk into a creek. I will look at certain features associated with the visible and invisible realms of these spirits, and show how these realms are intertwined. The article in many ways is a further reflection on the theme of the carved spirit-crocodiles I have already explored in several publications, including my own contribution to the above-mentioned catalogue (Telban, 2015a, b; see also Vávrová, this issue). I have analysed the importance of carved spirit-crocodiles for the Ambonwari, their place in the men's houses, their

1. The first version of this article was presented at the workshop Artefacts of Time: Transoceanic Transactions, held at The Cairns Institute, James Cook University (25-26 July 2013). Subsequent versions were delivered at the Research Centre of the Slovenian Academy of Sciences and Arts (8 September 2016) and at the Australian Anthropological Society Conference, The University of Sydney (13 December 2016). I thank Michael Young and Sasha Aikhenvald for their comments on a draft version of this article. 
roles in different practices including initiation rituals and all-night singing and dancing events, and the meanings of details carved on their backs (Telban, 1998: 189-195; 2008, 2014a). Various insights were further contextualized by other Sepik scholars, especially those who are specialists in Sepik art (Kaufmann, 2003: 70-75; 2009: I; Craig, 2010: 140; Howarth, Craig and Wilson, 2015: 206-207).

\section{Searching for an outboard motor that sank into a creek}

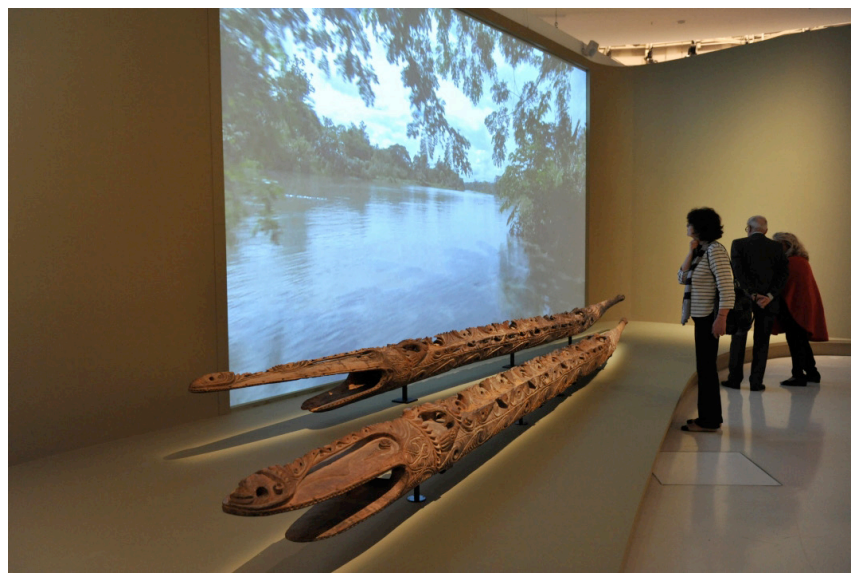

Рното 2. - Carved spirit-crocodiles from the Karawari-speaking village of Konmei exhibited at the musée du quai Branly

The middle Karawari region in the East Sepik Province of Papua New Guinea includes the Karawari-speaking villages of Masandanai, Manjamai, Konmei, Kundiman (two villages), Kungriambun, Kaiwaria, Meikerobi, and Ambonwari, and Arafundispeaking Imanmeri (see Map 1). With over 750 inhabitants, Ambonwari is the largest of eight Karawari-speaking villages, and of a similar size to Imanmeri. Within all-encompassing cosmology, Ambonwari clans have different places of origin, different myths of origin, and also different spirit-beings with different personal names (Telban, 1998: 147-161, 179). ${ }^{2}$ For individual clans these differences are of prime importance while the relationship between clans is achieved and continually re-established through past and present gift presentations, exchanges and exogamous marriages. Not all Ambonwari clans had carved spirit-crocodiles but those who did were perceived as the founders of the village (Telban, 1998: 169-170, 179 and 2008, 2015a, b). Thus, the spirit-crocodiles, like the spirit-beings in different Sepik societies generally (see, for example, Harrison, 1985: 418-419 and 1990: 89-91), also participated in the creation and maintenance of ritual hierarchy in the village (for current social changes, see Vávrová, this issue).

Since the Catholic charismatic movement reached the village in December 1994 (Telban, 2009), Ambonwari people have slowly abandoned many of their rituals and other customary practices (male initiation, first menstruation ritual, post-mortem divination, the activities of ritual inaugurator (see below) and mothers of the village, and so on), the majority of which I was able to witness during my first long-term fieldwork between 1990 and 1992 (Telban, 1997, 1998, 2001, 2008, 2014a). All these practices sustained people's active relationships with the spirits of the land and the spirits of the men's house. By

rejecting these practices and consequently avoiding any relationships with the spirits (by not calling their names and not offering them food, betel nut, shells, money, etc.) the Ambonwari weakened these spirits' influence on people's lives. The actual existence of the spirits of the land and the spirits of the men's houses, however, has never been questioned.

Maintaining a balanced relationship between people, the spirits of the land, and the carved spirit-crocodiles from the men's houses was in 1991 still of supreme importance. In the following recapitulation of a distressing event I will show how different dreams, signs, and speculations about possible causes were interrelated, and how a wooden spirit-crocodile was activated to participate in solving the problem. The incident happened shortly after Robert of Wallaby clan returned to Ambonwari, having spent seven years on Norfolk Island in Australia. He had been taken there by a couple of tourists who in agreement with his parents had organized all necessary documents for his temporary migration. Among the many gifts Robert brought home was an outboard motor which he gave to his classificatory father Brian of Wallaby clan. His maternal relatives organized a kurang ceremony (known as naven among the Iatmul; see Bateson, 1958) on his behalf but in their excitement they ignored the request to organize a similar ceremony for a new outboard motor. This latter ceremony involves simirinyar (ritual inaugurator; see Telban, 1998: 105-108) and is performed whenever an important object such as a large motor canoe, a carved crocodile, or a men's house is completed, or when an outboard motor is acquired. In this kind of a blessing ceremony the thing receives a

2. Severi writes: "[What] we anthropologists tend to call 'cosmologies' are de facto regularities in the establishment of a number of shared assumptions, very rarely expressed in the form of an explicit argument, and always related to specific practices, systems of relationships, and genre of discourses, either ritual or mythological.” (Severi, 2013: 195, 2014: 62). 


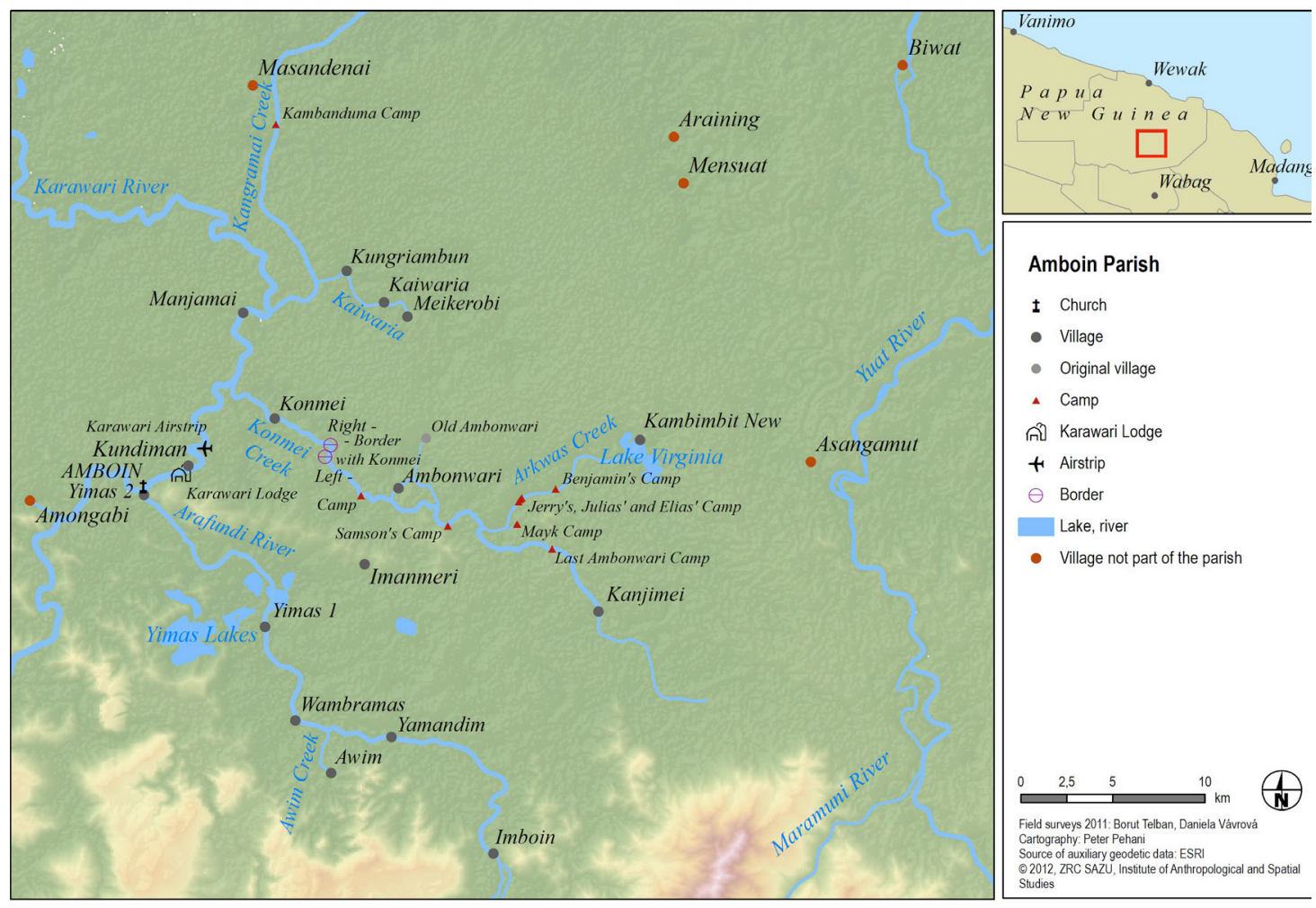

MAP 1. - Amboin Parish covers all Karawari-speaking villages with the exception of Masandenai and its Seventh-day Adventist Church, 2012 (@) Institute of Anthropological and Spatial Studies, ZRC SAZU)

personal name and becomes a spirit-being. This newly carved or acquired spirit-being holds the same name as his predecessor and is perceived as being the very same.

On 4 May 1991, my village sister's husband Godfried of Eagle clan (but importantly, his late mother was of Wallaby clan) dreamt about all-night singing and dancing that had lasted for three days. In that dream, he saw me in the morning after the last dance-night following him to the creek to bathe. He noticed a dead man in my large motor canoe, tied up with a vine like a pig to a carrying pole. The dead man's eyes were deep in his skull and his tongue was sticking out. There was a bunch of betel nuts on the body. Godfried dreamt that when I saw the body I ran away, frightened, carrying a coconut leaf. In his dream I told Godfried that I had taken the leaf so that the body could have been cut and that his wife Juana could have cooked its parts. I asked about the dead man's name but Godfried did not recognize him. We separated and walked to our houses. Then Godfried woke up and his dream ended. Later he told me that such a dream was a bad omen, indicating that someone was going to die. Because Godfried had dreamt about an allnight singing and dancing event some villagers remarked that boys' initiation should have been held in the village while I was still there.

The next day the new outboard motor which Robert had bought for his classificatory father Brian (both men are of Wallaby clan) sudden- ly unbuckled from the canoe during a test trip and sank into a creek. Albert of Pig clan (but see below for his relation to Wallaby clan) had been driving the canoe. He was devastated. Two young men dived into the creek and tried to recover the motor. The water was too deep, however, and they were unable to reach the bottom. They re-surfaced with traces of blood in their noses and ears. Albert thought that the whole incident had somehow been predicted the previous night when his wife had dreamt that their child (according to many denoting the motor) had drowned. Some people said that it was a punishment for the boastful behaviour of the young men of Wallaby clan while ignoring the request for the inaugural ceremony for the motor.

The search for the motor continued the next day. Wallaby clansmen attached hooks, used for catching crocodiles, to several thick vines and tried to pull the motor out of the water, without success. While they were paddling back to the village their large canoe began to rock (see Vávrová, this issue). People explained this as the anger of Warimindan, the carved spirit-crocodile from the men's house of Wallaby clan. They said that Albert's father had been born into Wallaby clan but was, while still a baby, given in adoption to Pig clan: the implication being that Albert should not mix with men of Wallaby clan - even though he was by birth their classificatory brother - but should stay with those of Pig clan. Upon hearing this, Albert became upset and said that he would 


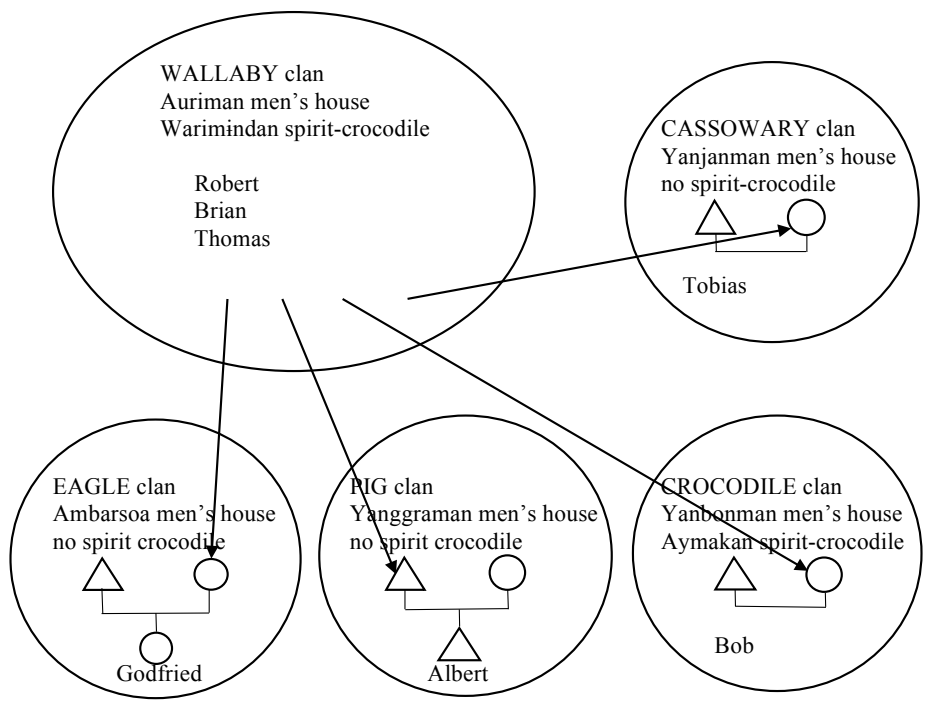

TABLE 1. - The most important actors and their relations to Wallaby clan in the event of an outboard motor that sank into the creek

buy a new motor for them and swear never to use it.

During the following days the young men of Wallaby clan asked Bob Kanjik, the big man of Crocodile clan, and Tobias Yangi, the village healer of Cassowary clan, for advice. Both knowledgeable men were married to the women of Wallaby clan. The men decorated sticks with money, shells and betel nut and visited all five men's houses, where they asked the spirits to help them. Tobias decorated his body and a stick with shells, rubbed his eyes with ginger, and walked to the river. He later explained that the spirits had appeared in front of his eyes but had not revealed where the motor had sunk. All subsequent divers' attempts were unsuccessful. Deep in the creek they found only some soaked logs and branches. That night Godfried again dreamt about me calling the young boys who were about to be initiated. Several villagers thought that the dream simply confirmed that the spirit-crocodiles were angry because the members of Wallaby clan had not yet organized the initiation ritual which I was supposed to witness.

On Sunday 12 May 1991, a large meeting was held in the main men's house called Yanbonman belonging to Crocodile clan. Another possible cause for the lost motor was suggested: Robert's mother was slandering all those who, in her view, had only accompanied her son on his trip to Angoram because they expected he had brought them many things from Norfolk Island. Bob Kanjik grew annoyed with the main spirit of the village, Ibrismari, telling him that he would not be given a pig's head if he did not help them. Then he remarked:

"Every place in the world has its own way and its own spirit of the place ... the spirit of the place is always there. One cannot baptize him nor throw him away.
This is not a belief. This is a fact! That's how it is!"

Brian and Albert asked Ibrismari for a sign to guide them to further action. They said that at least nobody had died, and that the spirits chose to take the motor instead. Bob Kanjik then said that Ambonwari spirits should now compete between themselves to determine which one would solve the problem. He proposed that a large feast be held in the men's house of the spirit-crocodile who succeeded in recovering the motor. Then he praised Warimindan, the wooden spirit-crocodile of Wallaby clan, saying how powerful he was, how many strong warriors had come out of his men's house, and how many enemies he had helped to kill. That night Bob dreamt about Ibrismari with a long beard and hair covering his face. He dreamt how a thick vine with a huge hook attached to it was thrown into the river, and he heard the noise of the hook hitting the motor. In his dream he called the young men who dived at that spot and in their third attempt finally found the motor. Bob understood his dreams as Ibrismari's sign that he was prepared to help. The next day, more than a week after the incident, the young men of Wallaby clan finally recovered the motor from the creek.

Next night Thomas, an old man of Wallaby clan, dreamt how their attempts to recover the motor were actually helped by the wooden spirit-crocodile Warimindan from their men's house. In his dream Thomas and his clan's spirit-crocodile Warimindan encountered a dangerous bush spirit-crocodile who scared him. Warimindan calmed him down, saying that if the bad spirit-crocodile had come closer he would have broken him in half. The fight between the two spirit-crocodiles began. The bush spirit suddenly metamorphosed taking on a human image with long hair and a beard both reaching to the waist of his naked body. Thomas recognized in him Marianmari, the bad spirit from the place called Marian, the land and the creek where the motor had sunk. The bad spirit in human form looked at him and then ran away.

Thomas' dreams confirmed that in the end it was their wooden spirit-crocodile Warimindan who had helped them. This made sense to all as it was their motor that had sunk.

That same evening Wallaby clansmen thrust a stick decorated with shells, money and betel 
nut into the ground at the front of their men's house and thanked their wooden spirit-crocodile Warimindan. Next morning, a heavy thunderstorm hit the village. The villagers were convinced that Marianmari was showing his anger. A few weeks later the motor was brought to the Wallaby men's house, a proper inauguration ritual was performed and food distributed. The outboard motor finally became an Ambonwari being with a clear identity as belonging to Wallaby clan.

The example shows the complexity of relationships between individuals of Wallaby clan, between them and those related to them through a gift of a child (Albert's father) or marriage (Godfried's mother and Bob's and Tobias's wives came from Wallaby clan), between them and their carved spirit-crocodile Warimindan, and the spirits inhabiting the landscape (see Table 1). It also shows that those who were not related to Wallaby clan did not interfere in this affair. Dreams and different signs (such as the rocking canoe), after being speculated upon and interpreted, revealed the possible causes for an incident and suggested solutions for the problem. Throughout the event people followed particular ways in which various spirits, including the wooden spirit-crocodiles from different men's houses, were approached and asked to help the divers in their search. The wooden spirit-crocodiles were activated by an offering in the form of sawyar sakrim, a stick decorated with shells, money and a cluster of betel nuts. The same practice had been used many times in the past before hunting or fighting expeditions. The man who presented the offering first called the name of the spirit-crocodile or several of them - the spirit of the land and the spirit of the men's house to which the land belonged - and then told them why he came and what he wanted. A spirit-crocodile was expected to appreciate the offering and ensure a successful hunt or victorious fight. In this way all those who presented the spirit-crocodile with an offering made an effort to indicate the direction in which future events should unfold to achieve the desired end. It was the same on the occasion of the sunken motor. This relationship between the men and the spirit-crocodiles, however, was not simply a matter of course. The men had to observe certain taboos (not sleeping with their wives on the night preceding an intended action) and avoid wrongdoing (adultery, theft, and so on). Spirit-crocodiles remembered if they had been presented with a pig's head after helping people on previous occasions. There could be all sorts of reasons attributed to family and kin members whose recent deeds influenced the final outcome. Once the spirit-crocodile was called up by his name and received the offering, he became attentive to all the happenings in his clan and the village at large. He began to play an important part in the process of unfolding events. It was their spirit-crocodile who enabled people to enter the invisible domain of other powerful spirits, including the spirits of various places and creeks.

\section{Visible and invisible realms of wooden spirit- crocodiles}

\section{Among the Ambonwari, as among the Yakwoia,}

"their life-world is no less real in their dreaming than in their wakefulness." (Mimica, 2011: 49)

The domain which is invisible in a waking state is just as real as the visible one. The invisible domain is indispensable for the creation of the visible one. In fact, one enables the other. The distinction is only perceptual. A named carved spirit-crocodile is therefore a perfect example of transformation from the invisible world into the visible one. It is through his name that a spirit-crocodile will continue to exist in a new arim (skin, body). This new skin will preserve the main aspects of kay (way of doing things, manner, habit, custom) of his carved predecessor. His name, one might say, hints at and suggests both the skin and ways of doing things of a newly carved spirit-being. It is the name that confers identity and enables bodily existence; and it is bodily existence that requires a name. Although the name of a spirit-crocodile may be said to be ontologically superior to its temporary carved skin (see Moutu, 2013: 27 and passim), it is the latter which is needed to perform a desired action if, for example, initiation is to be wholly successful in the visible world. However, even during initiation it was in the invisible realm where the novices were devoured and then impregnated by the spirit-crocodiles to be reborn as new Ambonwari men, as the new crocodiles (Telban, 2008: 228). Equally, the spirits could gorge on invisible quantities of food when it was offered to them in the men's house. From the people's perspective, the invisible doings of spirits continue to make them sick, mislead the hunters on their trips, or make an outboard motor sink. To get a glimpse into this invisible domain, dream experience continues to be just as important as experience in a waking state. ${ }^{3}$ In dreams a person's spirit leaves the skin and wanders around in an otherwise - from the perspective of people when they are awake - invisible realm.

It is in the visible realm of his dream that a man who is supposed to carve a new wooden crocodile first encounters the spirit. Appearance of the 
spirit-crocodile in a dream tells the man that he should go into the forest where the right tree needed for the carving will come to him by itself. As people like to say:

\section{"A tree shows itself to the carver."}

The invisible domain of every newly carved spirit-crocodile, who was before his material manifestation known only by his name, becomes revealed when a small inauguration ritual brings the spirit into his new skin. Both domains are real and the carved crocodile is therefore not just an image of his own invisibility. The carved spiritcrocodile is his own visibility and invisibility at the same time. In his carved skin he incorporates both realms, which are divided only because of different modes of perception: one when a person sleeps, during the night, and another when a person is awake, during the day. Even when not carved by being called by his name - which begins and maintains a relationship between people and the spirit-crocodile - he exists within the possibility of being carved and becoming visible. The name enables a transition from night to day, from a state of dreaming to a state of being awake, from the immaterial spirit to the carved being. It is this possibility of materialization, which strengthens the spirit-being's invisible presence.

In the German (Telban, 2015a: 60) and French (Telban, 2015b: 60) editions of the catalogue accompanying the European Sepik exhibition I wrote a passage which is worth presenting in English as it succinctly summarizes the importance of names and how they bring together the past and the future, the people, the spirit-beings, and their landscape, and how this kind of identification brings the Karawari world into existence.

"The man who holds the name of the founder of his clan can fully identify with his primordial ancestor and claim that he is the founder. In the same way, in a ritual context he can also identify with the name, appearance, and strength of the spirit-crocodile of his clan and claim that he is the spirit-crocodile (Telban, 1998: 152-55, 2008: 220, 227; see also Bateson, 1946: $120)$. While in a mundane context these kinds of identification can appear to be playful metaphors and symbols, during a ritualized event they become inductive, change-producing transpositions (Telban, 2008: 226). Spirit-crocodiles are emplaced in the environment just as the environment is embodied in carved spirit-crocodiles. This means that if we look at the spirit-things as artefacts we can say that cosmology, and the landscape in which cosmology is embedded, holds the entire cultural substance of this art. We can also follow Anthony Forge and agree that their art, just as he argued for the Abelam, is about relationships, not about things (Forge, 1970: 290). We can go a step further and say that cosmology, social organization, and kinship, and temporalities and localities embodied in the artefacts, are themselves the Karawari art. By saying that they are Karawari art one needs to take into account that Sepik life-worlds were never autochthonous but had throughout a long history, often depicted in their myths, legends, and names, interweaved their paths and incorporated relationships with others."

Ambonwari have never carved spirit-beings inhabiting the land around their present day settlement. Thus, the main iminggan saki (spirit of the village), lying underneath Ambonwari, has never been carved. The spirits of the land and creeks, who share their individual personal names with the places which they inhabit, are perceived as beings who are these places (e.g. Ambarmari, Ibrismari, see Telban and Vávrová, 2010), and have also never appeared in carved forms. Images of bush spirits are occasionally carved for tourists, but they remain nameless, without any indication of clan membership; they have no ritual and (besides financial) no significance whatever for the villagers.

For certain larger rituals at the village level, the carved spirit-crocodiles, each belonging to a different clan, needed to be paired. They were warimbars (partners; institutionalized ancestral relationship between two lineages from different clans: originally matrilateral siblings; sons of two men of different clans who married sisters, see Telban, 1998: 101). The two spirit-crocodiles were therefore related to each other as kupan (older brother) and wasapuk (younger brother). ${ }^{4}$ That meant that the pair of spirit-crocodiles helped each other and shared things without demanding a return gift. Such a partnership between spirit-crocodiles was reflected in human counterparts, that is dancing partners who belonged to the same clans as their respective spirit-crocodiles, and who danced together just as their spirit-crocodiles did. In other words, when men danced in a men's house, the carved wooden spirit-crocodiles danced too in their own invisible realm. This was their kay, their way of doing things, their way of becoming.

The carved spirit-crocodiles that used to be hidden in the men's houses were therefore very special beings. Just as the ancestors were travellers and explorers with special powers who were able to transform into animals which later became totemic beings and emblems of distinctive clans, so were their carved spirit-crocodiles and other spiritbeings associated with the men's houses (e.g. slitdrums, flutes, all of them with individual names). One could say that both cosmogony and cosmology of Ambonwari were, and continue to be, nomadic. The named carved spirit-beings, including the named men's houses themselves in which the carved spirit-beings were hidden, moved together with the people, whether they were ancestors or successors. They mastered the paths through the

4. Kupan is also a term used for big man, paternal grandfather, and older ritual partner. 


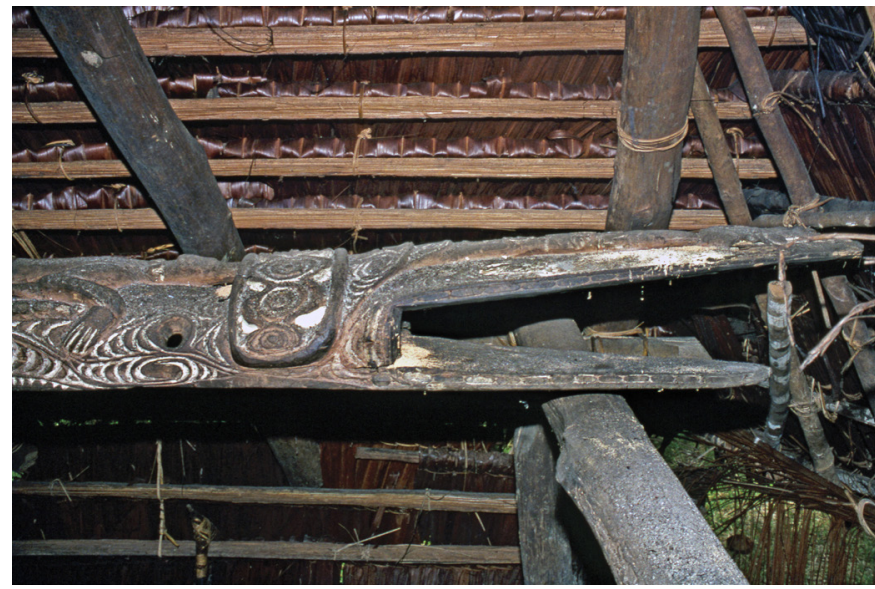

Рното 3. - Kongguniapan in Bird of Paradise men's house Wariman, 1991 (C) Borut Telban)

landscape and did not remain - in contrast to the spirit-crocodiles of specific places and creeks - attached to any single place. The place of the carved spirit-beings was their men's house (see photo 3 ). I would argue that their being was determined by their movements and was, whenever they were awake (during initiation rituals, for example), in a cosmogonic state of becoming. ${ }^{5}$ Their ways of becoming should therefore be seen in terms of a plurality of actualizations in and through their relationships with the people, other beings and the environment, all of which were the medium of their becoming. These relationships needed to be worked out whenever such becoming was requested as was the case in the example of an outboard motor that sank into a creek.

The carved spirit-crocodiles were there to roam, to act, and to change the world. Their exploring kay (way of doing things, habit, being) was intrinsic to their becoming. The wooden spirit-crocodiles were therefore not only past actualizations of themselves within a specific medium but also powerful entities embodying multiple potentialities for the future. The villagers were aware of these potentialities and knew the ways in which their powers could be employed for a desired goal to be achieved. They helped people to act upon their environment, their own relationships and relationships with their neighbours. They were able to dwell in-between what was visible and what was invisible. Their kay (way of doing things) was such that they acted upon the world by linking these seemingly separate domains. I write seemingly because for the Ambonwari there is neither absolute visibility nor absolute invisibility; one always encompasses the other, dwells within the other, needs the other (see Telban and Vávrová, 2014; Vávrová, 2014, also Vávrová, this issue). I would say that cosmology, ritual and art were therefore intrinsic to the carved spirit-crocodiles: they were all these and more. And because they were all these and more they were able to act upon the world in a specific way by transforming something that was concealed and invisible into something that was exposed and visible. In his most recent book Michael Jackson writes that

"art, religion, ritual, dance, and song are not essentially different phenomena but modalities, methods, or moments in which something hidden within is made manifest. Through this transformation of the latent into the patent, human beings realize their individual and collective capacity to act obliquely and vicariously upon the world - bringing it into being..." (Jackson, 2016: 17)

The majority of Karawari-speaking villages abandoned their men's houses together with associated rituals in the late 1950s and early 1960s. Bühler (1961: 186 f. n. 4) wrote that the carved crocodiles in Karawari villages lost their ritual significance in 1959 and were thrown away into the bush or burnt. However, as Bühler further noted, Ambonwari was one of the villages where they were retained. When a visiting crocodile hunter and occasional buyer of artefacts, Franz Panzenböck, purchased two wooden spirit-crocodiles there in 1963 the men performed de-sanctification rituals before he was allowed to take them away (Craig, 1992: 96). ${ }^{6}$ In Ambonwari, the carved spirit-beings, including four spirit-crocodiles - Kongguniapan of Bird of Paradise clan,

5. A note on what becoming means in this context is useful. At the end of Dancing through Time I wrote that kay (way, habit, being) as "a conceptualization of life itself, both collective and individual, confronts an open future. Its temporal horizon is time itself, which suggests not simply being but becoming. It may be proper, therefore, to see kay as a being whose being is becoming" (Telban, 1998: 1998: 230). How can this be understood? Wambung (insideness, understanding, centre of emotions and thoughts in the chest) is an "aspect of kay which is able, through transforming itself, to transform kay as well"; wambung is therefore "the means of kay's self-transformation" (Telban, 1998: 222, 229). Becoming is in Karawari language expressed by the verb si- as in wi mi stkan (it is getting dark) or maray kupay mi stkan (the high water is becoming/coming (up)). Whenever this verb is used with wambung - which in everyday life is extremely often - as in ama wambung ama stkan (I feel, I worry, I care, I like, I understand) it refers to a becoming of feelings and thoughts directed towards somebody or something (Telban, 1998: 56-62). This then becomes a necessary condition for any action and transformation.

6. The carved spirit-crocodile with arim (skin, body) also needs the anggindar kwanar (spirit, soul) of a living being (lit. watchman of a beam of light), which can be brought into the skin by calling its name and a small ceremony which includes a food offering. A similar ceremony would be performed for desanctification, which would release the spirit from its wooden enclosure. Old and abandoned carved spirit-crocodiles without their anggindar kwanar are nowadays called kambra arim (nothing skin, just skin), awur pinjing (piece of firewood), or just pinjinginar (piece of a male being, half thing). 
Aymakan of Crocodile clan, Kasmari of Hornbill clan, and Warimindan of Wallaby clan - were until 2001 hidden in the men's houses. Under the influence of the Catholic charismatic movement which began in December 1994 - interestingly, just a few months after the last initiation ceremony - the villagers decided that men's houses and wooden spirit-beings belonged to the past while God, Jesus and the Holy Spirit belong to the future (Telban, 2008 and 2009). It was then that carved spirit-crocodiles became invisible again. Their invisibility, however, did not negate them; their continuing existence has never been questioned by the villagers. Indeed, the invisible realm proved more resistant to change than the visible one. Nowadays, members of the Catholic Church and charismatic movement in Ambonwari perceive the ways of their ancestors and the world they sustained as undesirable, and neither their men's houses nor their wooden spiritcrocodiles are built and carved anymore. In other words, these beings are ignored by the majority of villagers (people say that they do not care about them), while their relationships with other entities (those of the Catholic Church) become the basis for multiple potentialities in the future.

\section{Conclusion}

In Ambonwari visible and invisible realms, just like day and night, constitute one world. By presenting the example of an outboard motor that sank into a creek I showed how these two realms appear to the villagers and how people are able to traverse the fluid boundaries between them. The wooden spirit-crocodiles hidden in Ambonwari men's houses, each with his own specific name, were beings who participated in either planned or accidental events which were important for the villagers. They connected the Ambonwari to the era of clan origins, to the movements and explorations of their first ancestors. The explorations from the times of cosmogony were therefore intrinsic to the carved spirit-crocodiles. They were able to bring the past into the future and the future into the past. Concealment and revelation enabled each spirit-crocodile to enter into an active relationship with those clansmen (living and dead clan members) who during the period of identification became him or were on their way to become him (the initiands, for example). The carved spirit-crocodiles and the members of their respective clans were therefore interdependent, and only by jointly engaging in their common becoming could they share a specific mode of existence, one that has been recently rejected by the members of the Catholic charismatic movement. The spirit-crocodiles and the spirits generally became present only when they were awake, that is, in a state of becoming. This becoming was facilitated through a combination of specific acts which (re)established the bond between people and spirits. Visual realization of a spirit-crocodile was therefore an intervention on the visual; it made the world appear in a particular way. It required from the men a perceptual immersion in a specific visualising mode of existence, which then became the foundation for their future actions. Once the world they brought into being became undesirable Ambonwari people began to give precedence to a different visualising mode of existence, one that appeared in dreams inspired by God and the Holy Spirit. The carved spirit-beings were then left to decay. However, whenever they appear in museums around the world as artefacts representing a particular life-world, they nevertheless reflect those dreams and the invisible realm which were necessary for them to be carved.

\section{REFERENCES}

Bateson Gregory, 1946. Arts of the South Seas (Exhibition Review), The Art Bulletin 28 (2), pp. 119-123.

\section{—, 1958. Naven, London, Wildwood House.}

BüHLER Alfred, 1961. Kultkrokodile vom Korewori (Sepik-District, Territorium Neuguinea), Zeitschrift für Ethnologie 86, pp. 183-207.

Craig Barry, 1992. National Cultural Property in Papua New Guinea: Implications for Policy and Action, Journal of the Anthropological Society of South Australia 30 (1 and 2), pp. 72-139.

Craig Barry (ed.), 2010. Living Spirits with Fixed Abodes: The Masterpieces Exhibition, Papua New Guinea National Museum and Art Gallery, Honolulu, University of Hawai'i Press.

Forge Anthony, 1970. Learning to see in New Guinea, in P. Mayer (ed.), Socialization: The Approach from Social Anthropology, London, Tavistock Publications, pp. 269-291.

Haberland Eike, 1975. Kannibalismus und Kultkrokodile am Mittleren Korowori (Sepik-Distrikt, Neuguinea), Abhandlungen und Berichte des Staatlichen Museums für Völkerkunde, Dresden 34, pp. 541-53.

Harrison Simon, 1985. Ritual hierarchy and secular equality in a Sepik River village, American Ethnologist 12 (3), pp. 413-426.

—, 1990. Stealing People's Names: History and Politics in a Sepik River Cosmology, Cambridge, Cambridge University Press.

Howarth Crispin (with contributions by Dr Barry Craig and Natalie Wilson), 2015. 
Myth + Magic: Art of the Sepik River, Papua New Guinea, Canberra, National Gallery of Australia.

JACKSON Michael, 2016. The Work of Art: Rethinking the Elementary Forms of Religious Life, New York, Columbia University Press.

Kaufmann Christian, 2003. Korewori: Magic Art from the Rain Forest, Honolulu, University of Hawai'i Press.

-, 2009. Spirit crocodile: ritual object and image of world order, in O. Wick and A. Denner (eds), Visual Encounters: Africa, Oceania, and Modern Art, Basel, Fondation Beyeler and Christoph Merian Verlag, p. I.

Mimica Jadran, 2011. Phenomenological psychoanalysis: The epistemology of ethnographic field research, in C. Toren and J. de Pina-Cabral (eds), The Challenge of Epistemology: Anthropological Perspectives, New York, Oxford, Berghahn Books, pp. 40-59.

Moutu Andrew, 2013. Names are Thicker than Blood: Kinship and Ownership amongst the Iatmul, Oxford, Oxford University Press.

Peltier Philippe, Markus Schindlbeck and Christian Kaufmann (eds), 2015a. Tanz der Ahnen. Kunst vom Sepik in Papua-Neuguinea, Munich, Hirmer Verlag.

-, 2015b. Sepik: Arts de Papouasie NouvelleGuinée, Paris, Skira, Flammarion/musée du quai Branly.

SeVeri Carlo, 2013. Philosophies without ontologies, HAU: Journal of Ethnographic Theory 3 (1), pp. 192-196.

—, 2014. Transmutating beings: A proposal for an anthropology of thought, HAU: Journal of Ethnographic Theory 4 (2), pp. 41-71.

Telban Borut, 1997. Being and 'non-being' in Ambonwari (Papua New Guinea) ritual, Oceania 67 (4), pp. 308-325.

-, 1998. Dancing Through Time: A Sepik Cosmology, Oxford, Clarendon Press.

-, 2001. Temporality of post-mortem divination and divination of post-mortem temporal- ity, The Australian Journal of Anthropology 12 (1), pp. 67-79.

—, 2008. The poetics of the crocodile: changing cultural perspectives in Ambonwari, Oceania 78 (2), pp. 217-235.

-, 2009. A struggle with spirits: Hierarchy, rituals and Charismatic movement in a Sepik community, in P. J. Stewart and A. Strathern (eds), Religious and Ritual Change: Cosmologies and Histories (Ritual Studies Monograph Series), Durham, N.C., Carolina Academic Press, pp. 133-58.

-, 2014a. The poetics of the flute: Fading imagery in a Sepik society, Folklore 125 (1), pp. 92-112.

—, 2014b. Saying, seeing and knowing among the Karawari of Papua New Guinea, in A.Y. Aikhenvald and R.M.W. Dixon (eds), The Grammar of Knowledge: A Cross-linguistic Typology, Oxford, Oxford University Press, pp. 260-277.

-, 2015a. Krokodile, Schlangen und die Jagd: Kosmologie und das traditionelle Glaubenssystem, in P. Peltier, M. Schindlbeck and C. Kaufmann (eds), Tanz der Abnen. Kunst vom Sepik in Papua-Neuguinea, Munich, Hirmer Verlag, pp. 54-61.

-, 2015b. Crocodiles, serpents et chasse : Cosmologie et système de croyances traditionnel, in P. Peltier, M. Schindlbeck and C. Kaufmann (eds), Sepik: Arts de Papouasie NouvelleGuinée, Paris, Skira Flammarion/musée du quai Branly, pp. 54-61

Telban Borut and Daniela VÁvrová, 2010. Places and spirits in a Sepik society, The Asia Pacific Journal of Anthropology 11 (1), pp. 17-33.

-, 2014. Ringing the living and the dead: Mobile phones in a Sepik society, The Australian Journal of Anthropology 25 (2), pp. 223-238.

Tischner Herbert, 1965. Das Kultkrokodil vom Korewori, Hamburg, Hamburgisches Museum für Völkerkunde und Vorgeschichte im Selbstverlag.

VÁVrová Daniela, 2014. 'Skin Has Eyes and Ears': Audio-visual Ethnography in a Sepik Society, Papua New Guinea, Ph.D. Thesis, James Cook University. 